\title{
Life-Cycle Dynamics in Industrial Sectors: The Role of Banking Market Structure
}

\author{
Nicola Cetorelli
}

A theoretical debate has emerged recently on the role of bank competition for economic activity in industrial sectors. In their seminal work on this issue, Petersen and Rajan (1995) have argued that young and unknown firms have easier access to credit if banks have market power. In their reasoning, banks with market power fund young firms with the expectation that they will be capable of extracting future rents once those firms become profitable. Petersen and Rajan's argument has immediate implications for predicting the role of bank competition on entry conditions in industrial sectors. Following their goal of profit maximization, banks with market power should be observed always to favor new entrants. This is because new entrants are potentially endowed with higher-return projects and more innovative technologies that would guarantee ever-increasing profit-sharing opportunities for the banks. Therefore, bank market power should continuously foster industry entry.

There is empirical evidence providing support for this argument. In addition to the aforementioned Petersen and Rajan (1995), Bonaccorsi di Patti and Dell'Ariccia (forthcoming) show that growth rates in the number of new enterprises are higher in markets with higher bank concentration. Cetorelli and Gambera (2001), although not focusing on entry, show that growth of industries where young firms are especially dependent on external finance is disproportionately higher in countries with higher bank concentration. There is also empirical evidence pointing in the opposite direction. Black and Strahan (2002), for example, show that business starts became more numerous in U.S. states after the relaxation of restrictions to entry in banking markets;

Nicola Cetorelli is a senior economist at the Federal Reserve Bank of Chicago and a Fellow of the Wharton Financial Institutions Center. The author thanks Jeff Campbell, Raghu Rajan, and seminar participants at the Federal Reserve Bank of Chicago and at the Federal Reserve Bank of St. Louis for comments. Any opinions expressed herein are those of the author and not necessarily those of the Federal Reserve Bank of Chicago or the Federal Reserve System.

(c) 2003, The Federal Reserve Bank of St. Louis. they also show a higher level of business starts in markets with lower bank concentration. Similar results are also found in Cetorelli $(2001,2003)$ and in Cetorelli and Strahan (2002).

The lack of univocal evidence may indicate the existence of a more elaborate mechanism through which bank competition affects economic activity in industrial sectors. The basic argument in Petersen and Rajan relies on the formation of long-time lending relationships and on the inherent value of such relationships for the bank. The latter is represented in their work by the present value of the future stream of profits of those firms the bank originally helped start up, firms that eventually become the industry incumbents. A possible theoretical "tension" embedded in this argument lies in the fact that the profitability of the older bank clients (and thus the bank's own profitability) will be affected by the entry of new firms. The bank may therefore face a potential trade-off: On the one hand, the bank could restrict access to credit for new entrants and continue its ongoing relationship with the industry incumbents; on the other hand, it could allow credit access to new firms, thus establishing new and possibly even more valuable relationships with them at the expense of the older clients. In recent papers, Cestone and White (forthcoming) and Spagnolo (2000) present theoretical frameworks in which existing lending relationships do indeed affect the behavior of lenders vis-à-vis potential new borrowers. The less competitive the conditions in the credit market, the lower the incentive for lenders to finance newcomers. Hence, financial market competition can represent a form of barrier to entry in product markets. ${ }^{1}$

What emerges from this discussion is that the effect of banking market structure and competition may have heterogeneous effects across firms within an industrial sector. More precisely, the effect may be different for start-ups and incumbents, thus implying that bank competition may have an impact on the entire life-cycle dynamics of industrial sectors,

\footnotetext{
1 This work is itself based on contributions to the issue of product market competition, such as Brander and Lewis (1986), Chevalier (1995), Kovenock and Phillips (1995, 1997), and Maksimovic (1988)
} 
and not just on entry. More or less bank competition affects not only entry but also the likelihood that young firms will survive and expand after entry. Once again, in keeping with the theoretical arguments illustrated above, more or less bank competition will also have an impact on the ability of the more mature firms (the incumbents) to prosper and, eventually, on the pace at which they will exit the industry.

This paper reflects a first attempt to examine the effect of bank competition on the life-cycle dynamics of industrial sectors. More precisely, I measure the effect of bank competition on the rates of job creation and destruction in U.S. manufacturing plants belonging to different age groups. If bank market power enhances the access to credit of young firms and accelerates exit of the more mature ones, then we should expect-all else being equalhigher rates of job creation and/or lower rates of job destruction among young firms, and lower rates of job creation and higher rates of job destruction among older firms. The opposite should be true if, instead, banks with market power tend to maintain close ties with incumbent firms and to create a financial barrier to entry in product markets.

The following section illustrates the data sets I have used for this study. Next, I describe the methodology for identifying the effects of bank competition and present the results of the empirical analysis. A summary of the results, highlighting caveats and unresolved issues, is presented in the conclusion.

\section{DATA SET}

The empirical testing of these propositions calls for a data set with information on industry dynamics, including specific details on the real activity of both start-ups and mature firms. The Davis, Haltiwanger, and Schuh (1996) data set on job creation and destruction in U.S. manufacturing sectors is a good example of a data set with these characteristics, one which to the best of my knowledge has yet to be used to analyze the potential effects of credit market characteristics on the life-cycle dynamics of industrial sectors.

This data set collects information on establishments' rates of job creation and destruction elaborated from the Longitudinal Research Database of the Census Bureau's Center for Economic Studies. The database contains information on individual U.S. manufacturing plants with five or more employees, collected through the quinquennial Census of Manufactures and the Annual Surveys of Manu- factures. The publicly available version of the data set, at its finest level of detail, contains information aggregated across establishments belonging to the same two-digit standard industrial classification (SIC) manufacturing sectors; it comprises nine census regions (New England, Middle Atlantic, East North Central, West North Central, South Atlantic, East South Central, West South Central, Mountain, Pacific) from 1973 to $1988 .^{2}$ Data is presented at this level of disaggregation on the rates of job creation and destruction among both "start-ups" and "continuing" establishments. An establishment is defined as a start-up in a given year if it shows up in the survey for the first time in that year. An establishment is defined as a continuing one in a given year if it was already present in the survey the previous year. ${ }^{3}$ Note, however, that the rates of job creation for the two age groups (start-ups and continuing establishments) are reported only as components of the total rate of job creation. ${ }^{4}$ In other words,

$$
g_{t}^{T}=g_{t}^{B} \cdot \text { empshare }_{t}^{B}+g_{t}^{C} \cdot \text { empshare }_{t}^{C},
$$

where $g_{t}^{T}$ is total job creation rate, $g_{t}^{B}$ the growth rate for start-ups, empshare $t_{t}^{B}$ the employment share of start-ups, $g_{t}^{C}$ the growth rate for continuing establishments, and empshare ${ }_{t}^{C}$ their employment share. The data set contains information for the two products on the right-hand side but not for the growth rates separately, or for relative employment shares. Hence, the data on job creation for each of the two age categories is somewhat interdependent, which implies that these data on job creation can be used only to estimate the relative effect of bank competition on one group with respect to the other.

There exists, however, an alternative format of the Davis, Haltiwanger, and Schuh (1996) data set that is also publicly available. This data set has a coarser level of disaggregation, with information available only over time and across census regions but aggregated across industrial sectors. While lacking the industry dimension, this alternative data set has the important advantage of providing the rates of job creation and destruction for three different age categories: establishments up to one year old (observed only in the current year), those between

\footnotetext{
2 Data through 1993 are available to the public, but at a higher level of aggregation - which is not relevant for this study.

3 For complete classification criteria of start-ups and continuing establishments, see Davis, Haltiwanger, and Schuh (1996, Table A3, p. 202).

4 This comment does not apply to the rates of job destruction.
} 


\section{Table 1}

\section{Job Flows by Establishment Age}

\begin{tabular}{lccc} 
Age categories & Job creation & Job destruction & Employment share \\
\hline Start-ups & 48.70 & 11.00 & 2.70 \\
Middle-aged & 12.20 & 13.70 & 17.50 \\
Mature & 7.09 & 9.30 & 79.70
\end{tabular}

NOTE: Start-ups are establishments up to one year old, middle-aged establishments are those between two and ten years old, and mature establishments are more than ten years old. The statistics are averages across regions and industrial sectors for the period 1977-88.

two and ten years old, and those older than ten years. ${ }^{5}$ Davis, Haltiwanger, and Schuh define the first group, again, as start-ups, the second as "middleaged," and the third as "mature."

In addition to a finer level of detail on the age profile of industrial establishments, the rates of job creation and destruction in this alternative data set are reported as actual growth rates for each age category, rather than components of the total job creation rate across categories. Thus, the first data set includes a third (cross-industry) dimension but does not provide independent information on job creation rates between start-ups and the complementary age group of the continuing establishments. The second data set lacks the cross-industry dimension but has superior information related to the age profile of manufacturing establishments. Gathering evidence from both data sets should allow me to draw as complete a picture as possible of the effect of bank competition on job creation rates. Table 1 presents year averages for the rates of job creation and job destruction and employment share for the three age categories of start-ups, middle-aged, and mature establishments.

The data on industry structure was matched with information from the FDIC Summary of Deposits, from Jayaratne and Strahan (1996), and from Compustat. From the Summary of Deposits, I have calculated Herfindhal-Hirschman indices of market concentration, measures of total bank assets, and total bank loans for each of the nine census regions. Jayaratne and Strahan (1996) used dummy variables to describe the process of banking deregulation occurring across U.S. states. Both intrastate and

\footnotetext{
5 The classification of the age categories varies slightly over time. At one extreme, in some years the ranges are less than 2 years old, 2 to 8 , and older than 8. At the other extreme, for some years the ranges were less than 3,3 to 12 , and older than 12 .
}

interstate restrictions on branching and on the creation of de novo banks existed to differing degrees in all U.S. states in previous decades. This meant substantial restrictions to entry in local markets and, consequently, a significant impact on the degree of banking competition. Starting in the 1970s, states began a process of relaxing such restrictions that continued throughout the early 1990s. Jayaratne and Strahan (1996) have shown that, as a result of increased competition, state economic growth accelerated after deregulation. Based on their indicator variables constructed at the state level, I have constructed an equivalent indicator for each region, using state income levels as weights, which captures the process of relaxation of restrictions to interstate bank branching. Figures 1 and 2 illustrate the time path of bank concentration and of the deregulation indicators constructed for the nine regions.

Taking advantage of the first data set's availability of establishment information from a cross-section of industrial sectors, I have augmented the estimations according to the differences-in-differences approach first suggested by Rajan and Zingales (1998). As these authors highlight, industrial sectors differ from one another, for technological reasons, in terms of their degree of dependence on external sources of finance. It must therefore be the case that, whatever the effect of bank concentration and bank deregulation on the life-cycle dynamics of a sector, this effect must be especially strong for those sectors that rely more heavily on external finance for their investment needs. For this reason, and following Rajan and Zingales, I constructed data on external financial dependence for each two-digit sector using information available in Compustat.

Data from the Summary of Deposits was available only from 1977, so the merged data, in its most 


\section{Figure 1}

\section{Banking Deregulation by Census Region}
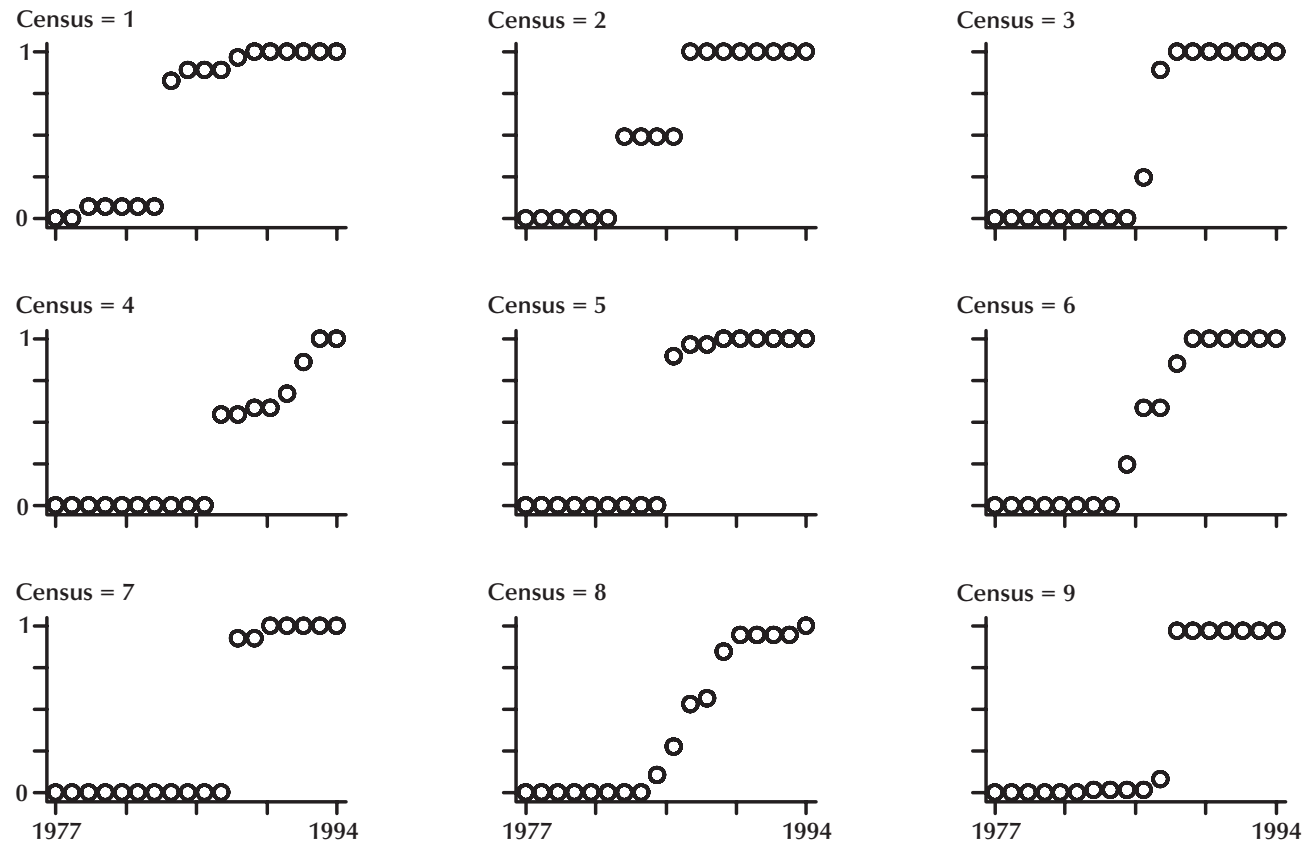

\section{Figure 2}

\section{Bank Concentration by Census Region}
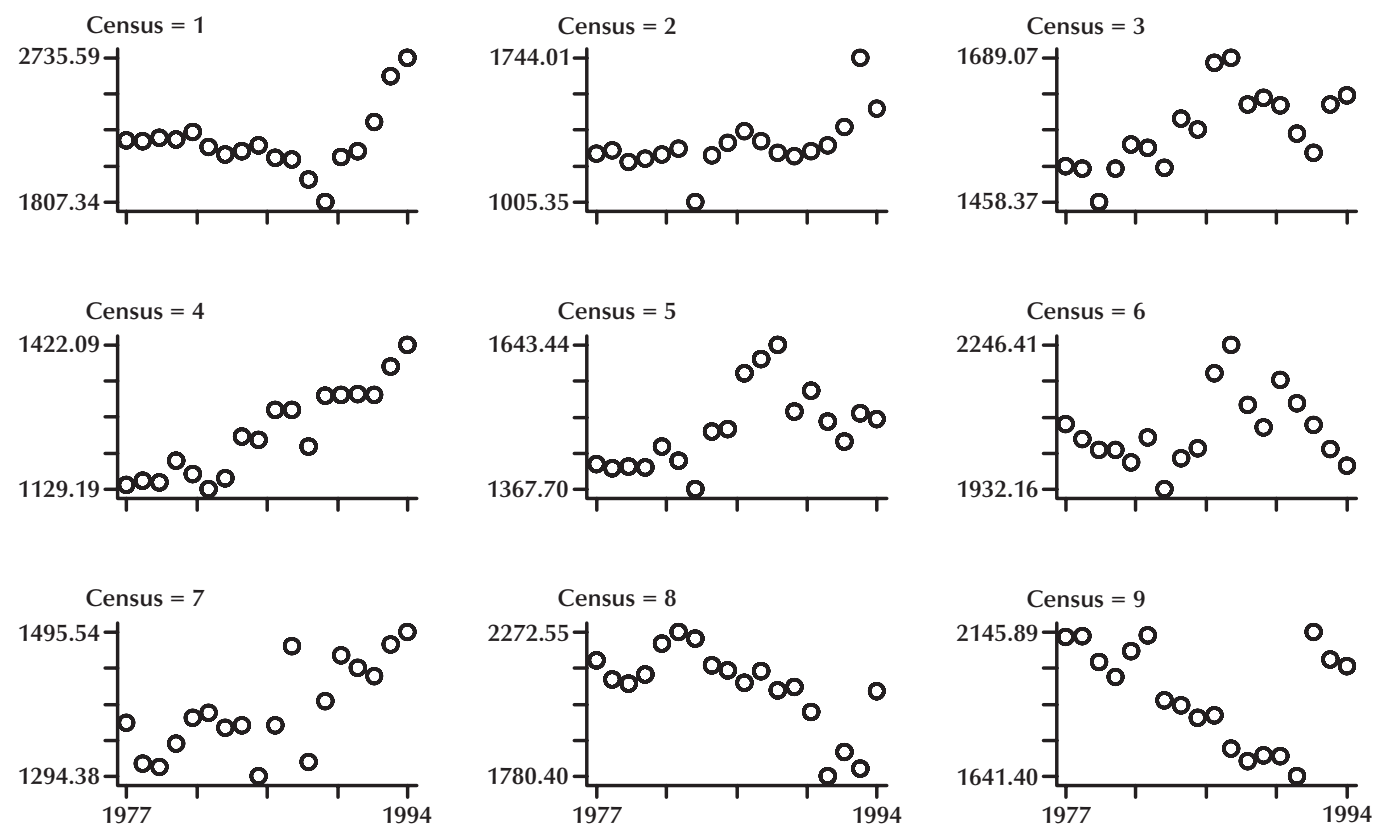
extensive format, runs from 1977 through 1988 , with information for 9 regions and 20 manufacturing sectors.

\section{EMPIRICAL TESTING}

Because the information on real economic activity for establishments in different age categories is so detailed, it is possible to test hypotheses about the specific mechanisms through which bank concentration and banking deregulation may impact the life-cycle dynamics of industrial sectors. Evidently, industries' employment dynamics, and what they imply in terms of industry entry and exit, are the results of many more factors, possibly even of a higher order of importance than the prevailing characteristics of the credit market. Such factors may be specific to each industrial sector, or they may be common across sectors for firms operating in a certain geographical area, or they may have a temporal component. The richness of a data set with multiple dimensions makes it possible to identify the effect of the bank competition variables, which vary across both region and time, while still controlling with vectors of dummy variables for effects that are specific to a given geographical region, are related to time passing, or are industry specific. This approach should substantially reduce the risk of a bias in the estimations due to the omission of relevant variables. As mentioned above, I also use information on the financial needs of each industrial sector; where possible, I also augment the estimation of the effects of the bank competition variables by using terms of interaction of such variables with the indicator of external financial dependence constructed from Compustat data.

Details of the methodology are more easily understood by looking directly at the models used for the estimation analysis. The basic strategy is to analyze the effect of the bank competition variables on establishments in the different age groups. I begin by focusing on the possible effect of bank competition on start-up plants. If bank market power enhances credit access to the youngest firms, then we should find that, all else equal, the rates of job creation of start-ups should be higher if bank concentration is higher and if banks face tighter regulatory restrictions. The opposite is true if, instead, one argues that banking market power may in fact represent a financial barrier to entry in product markets.

Using the second data set, I first estimate the following model:
(2)

$$
\begin{aligned}
& \text { Job creation of } \text { start-ups }_{r t}= \\
& \alpha_{r} \text { Regional dummies }_{r}+ \\
& \alpha_{t} \text { Year dummies }_{t}+\beta \text { Deregulation }_{r t}+ \\
& \gamma \text { Bank concentration }_{r t}+\eta \text { Controls }_{r t}+\text { Error }_{r t},
\end{aligned}
$$

where the dependent variable is the actual rate of job creation of start-up establishments in region $r$ and in year $t$. The vectors of indicator variables absorb region-specific and time-specific effects. The deregulation and bank concentration variables contain both a time and a geographic dimension and are therefore identifiable. If bank market power enhances entry, then we should expect $\beta$ to be negative and significant and $\gamma$ to be positive and significant. The opposite is true under the more traditional hypothesis that bank competition has a positive effect on the real economic activity of start-ups.

Subsequently, I look for confirmation of any result obtained with this first model specification by using the richer three-dimensional panel. As explained above, since this data set presents rates of job creation for start-ups and continuing establishments only as components of the total job creation rate, I can only test how either job creation rates for each age group contribute to the total. More precisely, I estimate the following alternative model specification:

(3)

( Job creation of start-ups/Total job creation $)_{r s t}=$ $\Delta_{r}$ Regional dummies $_{r}+\Delta_{s}$ Industry dummies d $_{s}+$ $\Delta_{t}$ Year dummies $_{t}+\beta$ Deregulation $_{r t}+$

$\gamma$ Bank concentration $_{r t}+$ $\delta\left(\right.$ Deregulation $_{r t} \cdot$ External financial dependence $\left._{s}\right)+$ $\varphi\left(\right.$ Bank concentration $_{r t} \cdot$ External financial dependence $\left._{S}\right)+$ $\eta$ Controls $_{r t v}+$ $\lambda\left(\right.$ Controls $_{r t} \cdot$ External financial dependence $\left._{s}\right)+$ Error $_{r s t}$.

The dependent variable is the rate of job creation of start-ups in each industry $s$ in region $r$ in year $t$, relative to the total job creation rate. Note that, necessarily, any effect identified through this model specification implies a mirror image effect (of the same magnitude but opposite sign) on mature establishments. The three vectors of indicator variables absorb the sector-specific, region-specific, and timespecific effects. As above, the deregulation and bank concentration variables contain both time and geographic dimensions and are therefore identifiable. As mentioned earlier, this data set may also be exploited to disaggregate sector-specific characteristics, such as the needs for external funding. 
Following the methodological approach of Rajan and Zingales (1998), whatever the effect of the variables of bank competition, such an effect will be especially strong in sectors that are relatively more dependent on external sources of finance. The interaction terms with the external financial dependence variable capture these effects. If bank market power enhances entry, then $\delta$ will be negative and significant and $\varphi$ positive and significant.

Next, I focus on what happens to start-ups once they receive funding and begin to grow. Does bank competition help relatively young firms to thrive? To explore this issue I have analyzed the effect of bank competition on the persistence rates of startups. The finer details on age present in the second data set allow me to do that by looking at both the job creation rates and the job destruction rates for the middle-aged establishments. These are plants that in relatively recent times were start-ups but are not yet considered mature. The analysis of this age group is performed using the following model specifications:

(4)

$$
\begin{aligned}
& \text { Job creation of middle-aged establishments } s_{r t}= \\
& \alpha_{r} \text { Regional dummies }_{r}+\alpha_{t} \text { Year dummies }_{t}{ }^{+} \\
& \beta \text { Deregulation }_{r t}+\gamma \text { Bank concentration }_{r t}{ }^{+} \\
& \eta \text { Controls }_{r t}+\text { Error }_{r t}
\end{aligned}
$$

and

(5)

$$
\begin{aligned}
& \text { Job destruction of middle-aged establishments }{ }_{r t}= \\
& \alpha_{r} \text { Regional dummies }_{r}+\alpha_{t} \text { Year dummies } \\
& { }^{+}+ \\
& \beta \text { Deregulation }_{r t}+\gamma \text { Bank concentration }_{r t}+ \\
& \eta \text { Controls }_{r t}+\text { Error }_{r t} .
\end{aligned}
$$

Finally, I analyze the effect of bank competition on the mature establishments. Given the dependence between the rates of job creation in the first data set, some indirect information on the role of bank competition for continuing establishments comes from the analysis of model (3). Analysis similar to those of models (1) and (4) can, however, be replicated by focusing on the job creation rates of the third cohort, that of the mature establishments:

(6)

Job creation of mature establishments $\mathrm{s}_{r t}=$ $\Delta_{r}$ Regional dummies $_{r}+\Delta_{t}$ Year dummies ${ }_{t}+$ $\beta$ Deregulation $_{r t}+\gamma$ Bank concentration $_{r t}+$ $\eta$ Controls $_{r t}+$ Error $_{r t}$.
Similarly, I analyze the potential effect of bank competition on the persistence rates of industry incumbents, thereby testing whether bank competition accelerates or slows down industry exit. To this end, I estimate the following model specification:

(7)

Job destruction of mature establishments $s_{r t}=$ $\Delta_{r}$ Regional dummies $_{r}+\Delta_{t}$ Year dummies ${ }_{t}+$ $\beta$ Deregulation $_{r t}+\gamma$ Bank concentration $_{r t}+$ IControls $_{r t}+$ Error $_{r t}$.

\section{RESULTS}

This section presents the results obtained during this first exploration of the data set. While the robustness of the results varies, they are nevertheless quite consistent across the various model specifications and allow us to form a coherent picture of the potential effects of bank competition on the life-cycle dynamics of nonfinancial industries.

\section{Effect on Entry (Start-ups)}

Table 2 presents the results of regressions based on model specification (2). The dependent variable is the actual growth rate of job creation among start-ups. As mentioned earlier, this second data set is characterized by information across regions and years only, but it has a finer level of detail on the age profile of establishments. Region and year indicator variables are included in the regressions though their estimates are not reported in the table. The regression results show that bank concentration is not significant, while the bank deregulation variable is positive and significant (at the 10 percent level) in three of four regressions. Employment share measures the relative size of all start-up establishments in a given region and year. Bank size, total loans, and total loans per capita are additional controls for characteristics of the banking industry.

The results from this set of regressions offer a first indication that bank competition, rather than bank market power, may provide better opportunity for entry in industrial sectors. Additional evidence of the potential effects on industry entry is extrapolated using the first data set. Table 3 displays regression results based on estimation of specification (3). Recall that the dependent variable is the rate of job creation of start-up establishments (in sector $s$, region $r$, and year $t$ ) relative to the total rate of job creation in each sector, region, and year. With this 


\section{Table 2}

\section{The Effect of Bank Competition on Start-ups}

\begin{tabular}{|c|c|c|c|c|}
\hline & 1 & 2 & 3 & 4 \\
\hline Bank concentration $_{r t}$ & $\begin{array}{c}-97.279 \\
(136.514)\end{array}$ & $\begin{array}{c}-191.597 \\
(158.453)\end{array}$ & $\begin{array}{c}-136.169 \\
(138.778)\end{array}$ & $\begin{array}{c}-93.899 \\
(138.366)\end{array}$ \\
\hline Bank deregulation $_{r t}$ & $\begin{array}{l}10.480^{*} \\
(6.425)\end{array}$ & $\begin{array}{c}8.424 \\
(6.500)\end{array}$ & $\begin{array}{c}11.423^{*} \\
(6.230)\end{array}$ & $\begin{array}{l}10.600^{*} \\
(6.468)\end{array}$ \\
\hline Employment share $_{r t}$ & $\begin{array}{l}-27.673^{* * *} \\
(10.227)\end{array}$ & $\begin{array}{l}-30.153^{* * *} \\
(10.649)\end{array}$ & $\begin{array}{l}-37.041^{* * *} \\
(11.290)\end{array}$ & $\begin{array}{l}-28.167^{* * *} \\
(10.360)\end{array}$ \\
\hline Bank size $_{r t}$ & & $\begin{array}{c}10.214 \\
(6.590)\end{array}$ & & \\
\hline Total loans $s_{r t}$ & & & $\begin{array}{c}-0.136^{* *} \\
(0.059)\end{array}$ & \\
\hline Total loans per capita rt & & & & $\begin{array}{c}-4.518 \\
(15.610)\end{array}$ \\
\hline Observations & 108 & 108 & 108 & 108 \\
\hline $\mathrm{R}^{2}$ & 0.82 & 0.83 & 0.83 & 0.82 \\
\hline
\end{tabular}

NOTE: The dependent variable is the rate of job creation of start-ups in each region $r$ and year $t$. Start-ups are defined as plants up to one year old. The time period is 1977-88. Bank concentration is the Herfindahl-Hirschman index calculated on bank deposits, aggregated across markets in each of the nine census regions $r$ over time. Bank deregulation is an indicator variable capturing the process of relaxation of bank entry restrictions in each region $r$ over time. Employment share measures the relative size of all start-up plants in region $r$ and year $t$. Bank size is an aggregate of bank total assets for banks in region $r$ and year $t$. Total loans is an aggregate of bank total loans for banks in region $r$ and year $t$. Total loans per capita is total loans divided by total region population. Region and year dummy variables are included in all regressions, but the coefficient estimates are not reported. Robust standard errors are in parentheses. $* * * / * * *$ denote significance at the $10 / 5 / 1$ percent levels, respectively.

dependent variable we can thus test if the contribution of start-ups to the total job creation rate increases or decreases depending on the competitive conditions in banking. Industry, region, and year indicator variables are included in the regressions though their estimates are not reported in the table. The results in the different specifications of the model indicate a negative and significant effect of bank concentration on the relative rate of job creation of start-ups. Consistent with this first result, the bank deregulation indicator is positive and significant (in two of four regressions) when interacted with external financial dependence. Both results thus indicate that the job creation rates of start-ups become relatively more important for the job creation rate of the industry as a whole as a result of improvements in bank competition.

Taken all together, the results from these first two models suggest that bank competition plays a positive role for start-ups, and that, in fact, bank market power may represent a form of barrier to entry in nonfinancial sectors.

\section{Persistence Rates of Start-ups}

The next step was to analyze the impact of bank competition on the "persistence" rates of start-ups: Once they are helped in the earliest stages of the life cycle, will the youngest establishments thrive under more or less competitive conditions in the banking industry? The results displayed in Tables 4 and 5 provide some indication that, if bank competition enhances industry entry, it also enhances their likelihood of survival in the first years of the life cycle. As Table 4 indicates, there is only tenuous evidence of a significant effect on the job creation of middle-aged establishments (those between two and ten years old); however, there is stronger evidence, reported in Table 5, that the rate of job destruction among middle-aged establishments is significantly lower in regions after states began the process of banking deregulation. Hence, this second set of results suggests that bank competition contributes to the success of newcomers. This is true at least in the sense that once they pass the start-up stage there is a decreasing likelihood of shrinking 


\section{Table 3}

\section{The Effect of Bank Competition on Start-ups (Relative Effect)}

\begin{tabular}{|c|c|c|c|c|}
\hline & 1 & 2 & 3 & 4 \\
\hline Bank concentration $_{r t}$ & $\begin{array}{c}-0.740^{* *} \\
(0.328)\end{array}$ & $\begin{array}{l}-1.367^{* * *} \\
(0.382)\end{array}$ & $\begin{array}{l}-0.909^{* * *} \\
(0.339)\end{array}$ & $\begin{array}{c}-0.757^{* *} \\
(0.330)\end{array}$ \\
\hline Bank deregulation $_{r t}$ & $\begin{array}{c}0.005 \\
(0.015)\end{array}$ & $\begin{array}{l}-0.013 \\
(0.016)\end{array}$ & $\begin{array}{c}0.011 \\
(0.016)\end{array}$ & $\begin{array}{c}-0.001 \\
(0.016)\end{array}$ \\
\hline Bank concentration $_{r t} \cdot$ External dependence $_{s}$ & $\begin{array}{c}-0.044 \\
(0.141)\end{array}$ & $\begin{array}{c}-0.047 \\
(0.140)\end{array}$ & $\begin{array}{c}-0.057 \\
(0.150)\end{array}$ & $\begin{array}{c}-0.119 \\
(0.157)\end{array}$ \\
\hline Bank deregulation $_{r t} \cdot$ External dependence $_{s}$ & $\begin{array}{c}0.023^{*} \\
(0.014)\end{array}$ & $\begin{array}{c}0.027^{*} \\
(0.014)\end{array}$ & $\begin{array}{c}0.024^{*} \\
(0.015)\end{array}$ & $\begin{array}{c}0.026 * \\
(0.014)\end{array}$ \\
\hline Employment share $_{r s t}$ & $\begin{array}{c}-0.010^{*} \\
(0.005)\end{array}$ & $\begin{array}{c}-0.010^{*} \\
(0.005)\end{array}$ & $\begin{array}{l}-0.010^{* *} \\
(0.005)\end{array}$ & $\begin{array}{c}-0.009 * \\
(0.005)\end{array}$ \\
\hline Bank size $_{r t}$ & & $\begin{array}{l}0.070^{* * *} \\
(0.018)\end{array}$ & & \\
\hline Bank size $_{r t} \cdot$ External dependence $_{s}$ & & $\begin{array}{c}-0.000 \\
(0.000)\end{array}$ & & \\
\hline Total loans $s_{r t}$ & & & $\begin{array}{l}-0.0004^{* * *} \\
(0.0001)\end{array}$ & \\
\hline Total loans $_{r t} \cdot$ External dependence $_{s}$ & & & $\begin{array}{c}-0.0002 \\
(0.0004)\end{array}$ & \\
\hline Total loans per capita $r t$ & & & & $\begin{array}{c}0.087^{*} \\
(0.052)\end{array}$ \\
\hline Total loans per capita $_{r t} \cdot$ External dependence $_{s}$ & & & & $\begin{array}{c}-0.042 \\
(0.029)\end{array}$ \\
\hline Observations & 2157 & 2157 & 2157 & 2157 \\
\hline $\mathrm{R}^{2}$ & 0.28 & 0.28 & 0.28 & 0.28 \\
\hline
\end{tabular}

NOTE: The dependent variable is the rate of job creation of start-ups in each region $r$, sector $s$, and year $t$, relative to total job creation - that is, the sum of job creation rates for start-ups and continuing establishments in each region $r$, sector $s$, and year $t$. Startups are defined as plants up to one year old; continuing establishments are a complementary group to start-ups. External dependence measures for each sector $s$ the degree of financial dependence on external sources of funding. Employment share measures the relative size of all plants in region $r$ and year $t$. See note for Table 2 for further explanations.

and shutting down in more competitive banking markets.

\section{Expansion of Incumbents}

The results of model specification (2) already pointed out, indirectly, that bank competition has a negative impact on the ability of older establishments to expand. Indeed, given the dependent variable in that model, any effect of bank competition on startups would be equal but with an opposite sign for the older plants. Using the second data set, we can look for confirmation of the negative role of bank competition on the ability of incumbents to expand, and focus specifically on the job creation rates of mature plants. The results of regressions from specification (6), as displayed in Table 6, indicate that job creation rates of mature plants are indeed higher in markets characterized by higher bank concentration. Hence, the continuing expansion of establishments, once they reach a mature age and attain the status of industry incumbents, seems to be enhanced by the presence of less competitive conditions in the banking industry.

\section{Persistence Rates of Incumbents}

The evidence gathered so far suggests that bank competition has an overall positive effect on the expansion and survival of younger establishments 


\section{Table 4}

The Effect of Bank Competition on the Persistence Rates of Start-ups: Effect on the Job Creation Rates of Middle-aged Establishments

\begin{tabular}{lcccc} 
& $\mathbf{1}$ & $\mathbf{2}$ & $\mathbf{3}$ & $\mathbf{4}$ \\
\hline Bank concentration $_{r t}$ & -4.704 & $-44.565^{*}$ & -13.334 & -3.213 \\
& $(23.205)$ & $(27.002)$ & $(23.163)$ & $(23.540)$ \\
Bank deregulation $_{r t}$ & 0.252 & -0.614 & 0.224 & 0.312 \\
& $(0.910)$ & $(0.867)$ & $(0.907)$ & $(0.911)$ \\
Employment share $_{r t}$ & -0.824 & -0.792 & -1.247 & -0.796 \\
& $(0.771)$ & $(0.727)$ & $(0.775)$ & $(0.776)$ \\
Bank size $_{r t}$ & & $4.217^{* * *}$ & & \\
Total loans & & $(1.196)$ & & \\
& & & $-0.020^{* *}$ & \\
Total loans per capita $_{r t}$ & & & $(0.010)$ & -2.185 \\
& & & & $(2.855)$ \\
Observations $^{2}$ & & & & 108 \\
$\mathrm{R}^{2}$ & 108 & 108 & 108 & 0.63
\end{tabular}

NOTE: The dependent variable is the rate of job creation of middle-aged establishments in each region $r$ and year $t$. Middle-aged establishments are defined as plants between two and ten years old. Employment share measures the relative size of all plants in the middle-aged group in region $r$ and year $t$. See note for Table 2 for further explanations.

\section{Table 5}

The Effect of Bank Competition on the Persistence Rates of Start-ups: Effect on the Job Destruction Rates of Middle-aged Establishments

\begin{tabular}{lcccc} 
& $\mathbf{1}$ & $\mathbf{2}$ & $\mathbf{3}$ & $\mathbf{4}$ \\
\hline Bank concentration $_{r t}$ & -7.883 & -0.643 & 0.631 & -13.023 \\
& $(25.459)$ & $(34.921)$ & $(26.384)$ & $(25.490)$ \\
Bank deregulation $_{r t}$ & $-2.748^{* *}$ & $-2.602^{* *}$ & $-2.868^{* *}$ & $-2.911^{* *}$ \\
& $(1.172)$ & $(1.238)$ & $(1.181)$ & $(1.170)$ \\
Employment share $_{r t}$ & 0.136 & 0.159 & 0.225 & 0.098 \\
& $(0.249)$ & $(0.260)$ & $(0.254)$ & $(0.261)$ \\
Bank size & & -0.725 & & \\
& & $(1.552)$ & & \\
Total loans $_{r t}$ & & & 0.020 & \\
Total loans per capita $_{r t}$ & & & $(0.013)$ & \\
& & & & 7.113 \\
Observations $^{2}$ & & & & $(4.909)$ \\
$\mathrm{R}^{2}$ & 108 & 108 & 108 & 0.85
\end{tabular}

NOTE: The dependent variable is the rate of job destruction of middle-aged establishments in each region $r$ and year $t$. Middle-aged establishments are defined as plants between two and ten years old. Employment share measures the relative size of all plants in the middle-aged group in region $r$ and year $t$. See note for Table 2 for further explanations. 


\section{Table 6}

\section{The Effect of Bank Competition on Incumbents' Expansion}

\begin{tabular}{|c|c|c|c|c|}
\hline & 1 & 2 & 3 & 4 \\
\hline Bank concentration $_{r t}$ & $\begin{array}{c}22.086^{* *} \\
(9.056)\end{array}$ & $\begin{array}{c}10.433 \\
(11.416)\end{array}$ & $\begin{array}{c}21.393 * * \\
(9.604)\end{array}$ & $\begin{array}{l}23.907^{* * *} \\
(8.393)\end{array}$ \\
\hline Bank deregulation $_{r t}$ & $\begin{array}{c}0.389 \\
(0.365)\end{array}$ & $\begin{array}{c}0.154 \\
(0.386)\end{array}$ & $\begin{array}{c}0.399 \\
(0.365)\end{array}$ & $\begin{array}{c}0.447 \\
(0.355)\end{array}$ \\
\hline Employment share $_{r t}$ & $\begin{array}{c}-0.050 \\
(0.144)\end{array}$ & $\begin{array}{c}-0.087 \\
(0.141)\end{array}$ & $\begin{array}{c}-0.057 \\
(0.150)\end{array}$ & $\begin{array}{c}-0.037 \\
(0.143)\end{array}$ \\
\hline Bank size $_{r t}$ & & $\begin{array}{l}1.167^{* *} \\
(0.573)\end{array}$ & & \\
\hline Total loans & & & $\begin{array}{c}-0.002 \\
(0.004)\end{array}$ & \\
\hline Total loans per capita $_{r t}$ & & & & $\begin{array}{c}-2.520^{*} \\
(1.321)\end{array}$ \\
\hline Observations & 108 & 108 & 108 & 108 \\
\hline $\mathrm{R}^{2}$ & 0.82 & 0.82 & 0.82 & 0.82 \\
\hline
\end{tabular}

NOTE: The dependent variable is the rate of job creation of mature establishments in each region $r$ and year $t$. Mature establishments are defined as plants more than ten years old. Employment share measures the relative size of all mature plants in region $r$ and year $t$. See note for Table 2 for further explanations.

and a negative effect on the expansion of mature ones. Table 7 shows evidence of the effect of bank competition on the persistence rates of incumbents. The dependent variable is the rate of job destruction of continuing establishments. The effect is picked up by the terms of interaction of bank concentration and bank deregulation with external financial dependence. The first term is negative and significant, while the second one is positive and significant in all four alternative model specifications. This result is confirmed, at least partially, from the results presented in Table 8, based on the alternative data set. In two of four specifications, bank concentration is negative and significant. Taken together, these results suggest that incumbent establishments do better in less competitive banking markets.

\section{CONCLUSIONS}

This paper has explored a new dimension of the economic role of bank competition. The empirical evidence shows that bank competition can have a significant impact on the entire life-cycle dynamics of nonfinancial industries. Some caveats remain present at this preliminary stage of analysis. As interesting as the data sets on job flows are, they still suffer from potentially relevant limitations in the width of the available information. Gaining access to the data at higher levels of disaggregation would certainly allow a more careful identification of the effects under study. The incorporation of additional control variables would also permit a higher degree of reliability.

These reservations notwithstanding, the data suggest important trajectories for further analysis. More competition in banking appears to promote job creation among industrial establishments at the start-up stage and to permit them to prosper in the immediate wake of their entry into the market. At the same time, more bank competition accelerates the exit of more mature establishments from the market. These results are consistent with theories suggesting that banking market power may represent a financial barrier to entry in product markets.

Another way to express the results is to say that bank competition has an effect on the age distribution of establishments within an industry. Let us refer to the statistics reported in Table 1, which describe job flows and employment share for each of the three age categories of industrial establishments over the period under analysis (1977-88). It is a stylized fact that, as the table indicates, on average start-ups have the highest rates of job creation and mature establishments the lowest; but the relative size of start-ups is very small compared with 


\section{Table 7}

The Effect of Bank Competition on Incumbents' Persistence Rates

\begin{tabular}{|c|c|c|c|c|}
\hline & 1 & 2 & 3 & 4 \\
\hline Bank concentration $_{r t}$ & $\begin{array}{c}1.826 \\
(5.548)\end{array}$ & $\begin{array}{c}3.803 \\
(6.997)\end{array}$ & $\begin{array}{c}2.996 \\
(5.656)\end{array}$ & $\begin{array}{c}1.499 \\
(5.586)\end{array}$ \\
\hline Bank deregulation $_{r t}$ & $\begin{array}{c}-0.228 \\
(0.231)\end{array}$ & $\begin{array}{c}-0.176 \\
(0.231)\end{array}$ & $\begin{array}{c}-0.280 \\
(0.234)\end{array}$ & $\begin{array}{c}-0.277 \\
(0.231)\end{array}$ \\
\hline Bank concentration $_{r t} \cdot$ External dependence $_{s}$ & $\begin{array}{c}-5.659 * * \\
(2.381)\end{array}$ & $\begin{array}{c}-5.670^{* *} \\
(2.389)\end{array}$ & $\begin{array}{l}-6.439 * * * \\
(2.463)\end{array}$ & $\begin{array}{c}-5.842^{* *} \\
(2.700)\end{array}$ \\
\hline Bank deregulation $_{r t} \cdot$ External dependence $_{s}$ & $\begin{array}{c}0.526^{* *} \\
(0.220)\end{array}$ & $\begin{array}{c}0.539 * * \\
(0.226)\end{array}$ & $\begin{array}{l}0.591^{* *} \\
(0.231)\end{array}$ & $\begin{array}{c}0.535^{* *} \\
(0.229)\end{array}$ \\
\hline Total job destruction $_{r s t}$ & $\begin{array}{l}0.612^{* * *} \\
(0.044)\end{array}$ & $\begin{array}{l}0.612^{* * *} \\
(0.044)\end{array}$ & $\begin{array}{l}0.611^{* * *} \\
(0.044)\end{array}$ & $\begin{array}{l}0.612^{* * *} \\
(0.044)\end{array}$ \\
\hline Bank size $_{r t}$ & & $\begin{array}{c}-0.204 \\
(0.336)\end{array}$ & & \\
\hline Bank size $_{r t} \cdot$ External dependence $_{s}$ & & $\begin{array}{c}-0.000 \\
(0.000)\end{array}$ & & \\
\hline Total loans $s_{r t}$ & & & $\begin{array}{c}0.003 \\
(0.002)\end{array}$ & \\
\hline Total loans $_{r t} \cdot$ External dependence $_{s}$ & & & $\begin{array}{c}-0.002 \\
(0.001)\end{array}$ & \\
\hline Total loans per capita $r t$ & & & & $\begin{array}{c}0.731 \\
(0.811)\end{array}$ \\
\hline Total loans per capita $_{r t} \cdot$ External dependence $_{s}$ & & & & $\begin{array}{c}-0.103 \\
(0.436)\end{array}$ \\
\hline Observations & 2157 & 2157 & 2157 & 2157 \\
\hline $\mathrm{R}^{2}$ & 0.75 & 0.75 & 0.75 & 0.75 \\
\hline
\end{tabular}

NOTE: The dependent variable is the rate of job destruction of continuing establishments in each region $r$, sector $s$, and year $t$. Continuing establishments are a complementary age group to start-ups. External dependence measures for each sector $s$ the degree of financial dependence on external sources of funding. Total job destruction is the sum of job destruction rates for establishments shutting down and establishments surviving in each region $r$, sector $s$, and year $t$. See note for Table 2 for further explanations.

older establishments. The results of the paper suggest that changes in bank competition may modify such distributions in nonfinancial sectors. More precisely, increases in bank competition should be associated with a shift of mass in the age distribution of job flows and size toward the younger establishments.

Much theoretical and empirical work has analyzed the relationship between establishments' age and job flows and, more generally, the determinants of the industrial life cycle. ${ }^{6}$ This paper makes a contribution to this literature by arguing that certain characteristics of the credit market-namely, its

\footnotetext{
6 See, e.g., Jovanovic (1982), Hopenhayn (1992), Evans (1987), Dunne, Roberts, and Samuelson (1989), and Davis and Haltiwanger (1992).
}

degree of competition - constitute one such determinant. It is worth exploring further what the findings of this analysis imply about the broad relationship of bank competition to industry structure, though here I will simply mention two possible implications. First, if concentration of market power in banking creates a barrier to entry in other industries, then we are suggesting that bank competition has a potential impact on the competitive conduct of nonfinancial markets. In addition, banking markets' role in delaying or accelerating processes of industry entry and exit may in turn be expected to impact the pace of adoption of technological innovations in industrial sectors. Thus, the dynamics explored in this analysis may ultimately have implications for economic growth. 


\section{Table 8}

\section{More on the Effect of Bank Competition on Incumbents' Persistence Rates}

\begin{tabular}{|c|c|c|c|c|}
\hline & 1 & 2 & 3 & 4 \\
\hline Bank concentration $_{r t}$ & $\begin{array}{c}-23.266^{*} \\
(13.645)\end{array}$ & $\begin{array}{c}-25.994 \\
(17.462)\end{array}$ & $\begin{array}{c}-17.483 \\
(14.569)\end{array}$ & $\begin{array}{c}-29.076^{* *} \\
(11.546)\end{array}$ \\
\hline Bank deregulation $_{r t}$ & $\begin{array}{c}-0.238 \\
(0.625)\end{array}$ & $\begin{array}{c}-0.293 \\
(0.653)\end{array}$ & $\begin{array}{c}-0.319 \\
(0.628)\end{array}$ & $\begin{array}{c}-0.422 \\
(0.582)\end{array}$ \\
\hline Employment share $_{r t}$ & $\begin{array}{c}-0.264 \\
(0.211)\end{array}$ & $\begin{array}{c}-0.273 \\
(0.213)\end{array}$ & $\begin{array}{c}-0.203 \\
(0.231)\end{array}$ & $\begin{array}{c}-0.307 \\
(0.224)\end{array}$ \\
\hline Bank size $_{r t}$ & & $\begin{array}{c}0.273 \\
(0.834)\end{array}$ & & \\
\hline Total loans ${ }_{r t}$ & & & $\begin{array}{c}0.014^{*} \\
(0.007)\end{array}$ & \\
\hline Total loans per capita $_{r t}$ & & & & $\begin{array}{l}8.041^{* *} \\
(3.611)\end{array}$ \\
\hline Observations & 108 & 108 & 108 & 108 \\
\hline $\mathrm{R}^{2}$ & 0.84 & 0.84 & 0.85 & 0.85 \\
\hline
\end{tabular}

NOTE: The dependent variable is the rate of job destruction of mature establishments in each region $r$ and year $t$. Mature establishments are defined as plants more than ten years old. See note for Table 2 for further explanations.

\section{REFERENCES}

Black, Sandra E. and Strahan, Philip E. "Entrepreneurship and Bank Credit Availability." Journal of Finance, December 2002, 57(6), pp. 2807-33.

Bonaccorsi di Patti, Emilia and Dell'Ariccia, Giovanni. "Bank Competition and Firm Creation." Journal of Money, Credit, and Banking (forthcoming).

Brander, James A. and Lewis, Tracy R. "Oligopoly and Financial Structure: The Limited Liability Effect.” American Economic Review, December 1986, 76(5), pp. 956-70.

Cestone, Giacinta and White, Lucy. "Anti-Competitive Financial Contracting: The Design of Financial Claims." Journal of Finance (forthcoming).

Cetorelli, Nicola. "Does Bank Concentration Lead to Concentration in Industrial Sectors?" Working Paper 2001-01, Federal Reserve Bank of Chicago, April 2001.

"Banking Concentration and Competition in Europe.” Unpublished manuscript, 2003.

and Gambera, Michele. "Banking Market Structure, Financial Dependence and Growth: International Evidence from Industry Data." Journal of Finance, April 2001, 56(2), pp. 617-48. and Strahan, Philip. "Banking Competition, Technology and the Structure of Industry." Unpublished manuscript, 2002.

Chevalier, Judith A. "Capital Structure and Product-Market Competition: Empirical Evidence from the Supermarket Industry." American Economic Review, June 1995, 85(3), pp. $415-35$.

Davis, Steven J. and Haltiwanger, John C. "Gross Job Creation, Gross Job Destruction, and Employment Reallocation." Quarterly Journal of Economics, August 1992, 107(3), pp. 819-63.

and Schuh, Scott. Job Creation and Destruction. Cambridge, MA: MIT Press, 1996.

Dunne, Timothy; Roberts, Mark J. and Samuelson, Larry. "The Growth and Failure of U.S. Manufacturing Plants." Quarterly Journal of Economics, November 1989, 104(4), pp. 671-98.

Evans, David S. "The Relationship Between Firm Growth, Size, and Age: Estimates for 100 Manufacturing Industries." Journal of Industrial Economics, June 1987, 35(4), pp. 567-81.

Hopenhayn, Hugo A. "Entry, Exit, and Firm Dynamics in 
Long Run Equilibrium." Econometrica, September 1992, 60(5), pp. 1127-50.

Jayaratne, Jith and Strahan, Philip E. "The Finance-Growth Nexus: Evidence from Bank Branch Deregulation.” Quarterly Journal of Economics, August 1996, 111(3), pp. 639-70.

Jovanovic, Boyan. "Selection and the Evolution of Industry." Econometrica, May 1982, 50(3), pp. 649-70.

Kovenock, Dan and Phillips, Gordon M. "Capital Structure and Product-Market Rivalry: How Do We Reconcile Theory and Evidence?" American Economic Review, May 1995, 85(2), pp. 403-08.

and "Capital Structure and

Product Market Behaviour: An Examination of Plant Exit and Investment Decisions." Review of Financial Studies, Fall 1997, 10(3), pp. 767-803.

Maksimovic, Vojislav. "Capital Structure in Repeated Oligopolies.” RAND Journal of Economics, Autumn 1988, 19(3), pp. 389-407.

Petersen, Mitchell A. and Rajan, Raghuram G. "The Effect of Credit Market Competition on Lending Relationships." Quarterly Journal of Economics, May 1995, 110(2), pp. 407-43.

Rajan, Raghuram G. and Zingales, Luigi. "Financial Dependence and Growth." American Economic Review, June 1998, 88(3), pp. 559-86.

Spagnolo, Giancarlo. "Debt as a (Credible) Collusive Device." Working Paper No. 243, Stockholm School of Economics, 2000 . 
148 JuLY/AUgust 2003 